\title{
Promotion of Fertilizer Application: A Major Factor to Maintain Food Security and Stability for Smallholders in Togo
}

\author{
Wasseh Emefa Germaine GBETE ${ }^{1}$, Nie Fengying ${ }^{2}$ \\ ${ }^{1,2}$ Agricultural Information Institute, Chinese Academy of Agricultural Sciences, \\ 12 Zhongguancun South Street, Haidian, 100081- Beijing, China
}

\begin{abstract}
Agriculture is the engine of economy and social development for many countries in Africa including Togo. Agriculture has large share of employment creation (54\%) and contributes significantly to gross domestic product (GDP) about 40\% [8]. This study analyzed the factors that are affecting the use of input in Togo's agricultural development, particularly maize. Based on the data collected in 2015, the analysis shows that farm size, gender of the household head, household size and belonging to farm cooperative are significant for all farmers due to their influence to the farmer's choice on input use. It also observed that access to market affected small farmers who are not close to the input market. The evidence from the empirical analysis revealed that the eight independent variables (farm size, farming experience years, age, head of household, duration of education, household size, belonging to farm cooperative, and access to market) contributed up to $76 \%$; $77 \%$ and $76 \%$ of the systematic variation in the agricultural fertilizers and seeds use in agricultural production. Special attention is needed to help farmers understanding the benefit of using inputs and good practices.
\end{abstract}

Keywords: Food security, inputs use, smallholder farmer, Agricultural productivity, Togo.

\section{Introduction}

Agriculture is the engine of economy and social development for many countries in Africa including Togo. Agriculture has large share of employment creation (54\%) and contributes significantly to gross domestic product (GDP) about $40 \%$ [8], a feature that is common among many developing countries. Agricultural production systems are expected to produce food for a global population which is around 7.12 million [43]. The precondition for the effective performance is also expected to contribute to foreign exchange earnings through increase in export and providing a major market for local industrial sector product and accelerate increase in agricultural output, income and resource [42]. Some agricultural economists believed that each increase cited above can only be achieved with introduction of new technology in traditional agriculture [16]. Technology is at the center of the "advancement of agricultural productivity growth in China" and institutional technical changes accounted for most contributions to the increase of Total Factor Productivity (TFP) of Chinese agriculture [1].

To secure and maintain food security, agricultural systems need to be transformed to increase the productive capacity and stability of smallholder agricultural production. However, there is a question of which technologies and practices are most appropriate to reach smallholder farmers.

As farmers adopt new techniques the productivity rise, which in turn give more productive farmers benefit from an increase in their welfare while farmers who are not productive enough will exit the market to seek success elsewhere [25].

The use of new agricultural technologies and practices has proposed to raise household incomes, slow rural-urban migration, and reduce pressure on natural resources (e.g., [28], [29]). Most research on agricultural intensification has focus on areas with high population densities and/ or market integration such as sub-Saharan Africa and southern Asia [27]. Population densities rise and/or demand for agricultural products increase, the resulting land pressures induce adoption of technological and institutional innovation to intensify land use [4] .

The principle sources of high productivity in modern agriculture are reproducible sources. They consist of particular material inputs and of skills and other capabilities required to use such inputs successfully [36]. Increase productivity need to use mechanization, high yield varieties, which were the basis of the green revolution which began in 1960s promoting application of fertilizers to balance soil $\mathrm{pH}$ and provide nutrients and minerals needed by plant to grow well [6]. Increased use of high external inputs sometimes caused farmers to abandon traditional techniques of soil fertility maintenance [2].

The Togolese agriculture is hand caped with the widespread use of basic equipment with very low productivity such as hand hoe, machete, sickle, pick, ax, stick, etc.. less than $1 \%$ of sown land apply mechanized and in 2012, 7 tractors were available for one thousand farmers [20].

Togolese agriculture depends on rainfed which impairs productivity and affects farmer's access to the banking facilities

Togolese agricultural sector faces several constraints among which are post-harvest losses, lack of credit, high cost and unavailability, timely agricultural inputs, lack of labor to agricultural labor or employee peak, climate variability, the lack of control of water, the low capacity of producer 


\section{International Journal of Science and Research (IJSR) \\ ISSN (Online): 2319-7064}

Index Copernicus Value (2013): 6.14 | Impact Factor (2014): 5.611

organizations, the high rate of illiteracy, non-remunerative prices for agricultural products, low rates agricultural land, lack of storage facilities, the scarcity and uneven distribution of access to agricultural microcredit and the lack of longterm financing of agriculture [31]. These constraints show that agriculture remains traditional and need more investments to overcome all those problems.

A study carried out on inputs market access in Togo shows that agricultural productivity is low (e.g. for maize production $900 \mathrm{~kg} / \mathrm{ha}-1200 \mathrm{~kg} / \mathrm{ha}$ ) due to several major constraints including low fertilizer use [18]. This results from the low purchasing power of the majority of farmers and insufficient supply. Fertilizer use by Togolese farmer generally remains dependent on the vagaries of the world market for cotton, coffee and cocoa.

The aim of this paper is to analyze the factors that are affecting the use of input in Togolese agricultural production particularly maize production. To understanding this we will present a brief overview of agricultural productivity and new agricultural technologies use.

\section{Literature Review}

\subsection{Input use in developing countries}

\subsubsection{Input use studies in developing countries}

Green Revolution took place and was successful in Asian countries, where by adoption studies started about four decades ago following the Green Revolution in Asian countries. Since then several studies have been undertaken in Asia and Latin America to assess the rate, intensity, and determinants of adoption.

A review on several empirical studies on the adoption of Green Revolution technologies revealed that the new High Yield Varieties (HYVs) of wheat and rice were adopted at a rapid rate in those areas where they were technically and economically superior to local varieties; and landowners have gained relatively more than tenants and laborers from the adoption of HYVs of wheat and rice [12]. Another study done by the Centro International de Mejoramieto de Maize Y Trigo (CIMMYT) on maize and wheat in six countries (Kenya, Tunisia, Colombia, El-Salvador, Mexico, and Turkey) concluded that the differences in adoption rates among those countries were explained by differences in information acquired, agro-climatic and physical environments, availability of inputs, differences in market opportunities for the crops, and differences in farm size and farmers $^{\text {ee }}$ risk aversion characteristics. A comprehension survey of agricultural technology adoption studies in developing countries by [11] and [10] also found that farm size, risk, human capital, labor availability, access to credit and land tenure systems were the most important factors in influencing farmers ${ }^{\text {ee }}$ decision of technology adoption.

Another study on the diffusion of fertilized grass-legume pastures in Uruguay followed the logistic path during the first years following its introduction. The study considered the number of ranchers borrowing money from the bank for pasture development each year as a proxy for new adopters of improved pastures. The information on borrowers provides a good estimate of total adopters and the rate of new adopters over time. Using panel data, studies by some authors, revealed that learning from own experience and learning from neighbors ${ }^{\text {ee }}$ experience are both important determinants of adoption [12].

\subsubsection{Diffusion of input use research in Africa}

In Africa, new agricultural technologies have been introduced in the mid-1970s and found success story achieved in Asia but failed in African countries except for hybrid maize in Kenya cited by [12].

The estimation of the interrelationships among technologies already adopted by maize farmers in Swaziland shows that farmers tend to adopt packages rather than individual technology component or practice [33].

A study on peanut research and poverty reduction to show the impacts of variety improvement to control peanut viruses in Uganda showed that sizable research benefits are generated by adopting Rosette-resistant varieties and the benefits accrue in open economy to adopting farmers [37].

Institutional Innovation for agricultural technology adaptation and adoption in the case of Rice in West and Central Africa discovered that by using multi-stakeholder assumed that the ROCARIZ used competitive research grants through multi-stakeholder task forces to generate, adapt, and facilitate the adoption of rice-based technologies and approaches by poor households [36].

\subsubsection{Linkage between using agricultural technology and agricultural productivity}

From some Policy research issues, the roles of new technology in agriculture, rural infrastructure, and prices in enhancing the process of poverty alleviation are increasingly well understood to the extent that clearer policy guidelines are emanating from research, same cannot be said of the role of rural financial markets in alleviating poverty. In the conventional approach to rural finance, the production side of rural farm households generally provides the rational for rural credit [45].

For the functional structure of Rural Financial Institutions (RFIs) and their System in general, multifunctional RFIs are defined as those that directly and indirectly undertake functions such as farm-level loans (both in cash and kind, and short-and longer-term loans for crops and other enterprises), extension, sales of farm inputs, marketing of farm produce, sale of consumer goods, collection of deposits, other borrowings, and loan recovery [5]. For agricultural growth, intermediate inputs (such as seeds and fertilizer), labor, and operating assets (such as wells, pump sets, and farm implements) are all required and complement each other. Credit makes it possible for farmers to have the inputs they need to realize the full potential of the new technology and hence to repay loans promptly.

The yield increasing advantage of MVs is lower in marginal areas. The observation implies that the more favorable the rice production environments, the greater the yield [15]

\section{Volume 5 Issue 1 January 2016}




\section{International Journal of Science and Research (IJSR) \\ ISSN (Online): 2319-7064}

Index Copernicus Value (2013): 6.14 | Impact Factor (2014): 5.611

Their review from the Asian experience shows that the landless poor and marginal farmers in the unfavored areas benefit, through labor migration, from the new technology adopted in the favored areas. The landless are also rice consumers and benefit from lower prices. They concluded that allocating research resources to the development of high input cereal technology for marginal agricultural areas cannot be justified from the viewpoint of either efficiency or poverty reduction and this conclusion was also supported by [31].

Furthermore, reduction in food prices will contribute to the preservation of forest resources because poor farmers who do not own sufficient land clear forests [31]. They suggest and argued that more resources should be allocated to research that generates appropriate technologies for such areas. The development and wide adoption of new and more efficient agroforestry system will both improve the incomes of poor farmers in marginal areas by increasing the efficiency of land use and contributing to partial restoration of forest environments. They finally conclude that if agricultural research ought to reduce poverty in marginal areas by developing new technologies in such areas, then it must focus on the development of appropriate technologies conducive to efficiency of resource use.

The studied carryout in Uganda on Peanut research and Poverty Reduction found that Agricultural research can significantly influence the level and the distribution of income and can reduce poverty in several ways. The results of their study using the poverty indices showed modest reduction in poverty, reflecting the fact that these surplus changes are distributed among a large number of peanut producing households; many of whom are not poor [37]. Technology adoption can lower per-unit cost of production, increase the supply of food, and raise incomes of adopting farmer. The poor also gains disproportionately as consumers from lower food prices, as they spend a high proportion of their income on food [40]. Higher productivity could also create broad-based multiplier effects within the rural community, inducing employment creation in industries related to agricultural production, such as value-added processing, and roadside marketing.

The potential impact of agricultural technology adoption on poverty alleviation strategies in two rural Bangladeshi regions found a robust and positive effect of agricultural technology adoption on farm household well-being and suggesting that there is a large scope for enhancing the role of agricultural technology in ,directlye contributing to poverty alleviation [23], [40].
The study of analysis of Micro credit as a veritable tool for poverty reduction among rural farmers in Anambra State in Nigeria showed that the effect of credit on livelihoods can be multidimensional and may not be fully captured by just a single household outcome [24]. However, it takes time before the effect of borrowing on livelihoods is fully materialized. The implications of these findings are that providing the farmers ${ }^{e e}$ access to higher amounts of credit will enable them improve their access to information [41]; adopt modern technologies and skills [26]; and achieve enterprise diversification [39]. This development will result to increase in productivity and income of the farmers, and consequently reduction of poverty level [24].

\subsection{Capital, fertilizers, credit market and productivity in Togo}

\subsubsection{Fertilizers and productivity}

State Policy for Development of the fertilizer market in Togo showed that Togolese agricultural production particularly food crops are facing with very efficient traditional practices [3]. Facing the low productivity observed by many researchers among farmer whose incurred food insecurity for population, Togo government have always wanted to see these practices migrate to the adoption of new technology packages in agriculture which mainly characterized by the green revolution years 1977 for Togo, initiated by former President General Gnassingbe Eyadema, Named "Schwartz 1988". This initiative involves the adoption of new technology (improved seeds and chemical inputs) allowed the development of certain crops such as cotton, coffee and cocoa. Unfortunately, food crops did not benefit from this revolution in the same manner as cash crops, due to the smallness of the fertilizer market intended for food crops in Togo.

Indeed, Africa accounts for 3\% of global fertilizer market and Togo represents a marginal share of $2 \%$ of fertilizer imports either 25 000tons of nutrients in West Africa (11\% of the African market). Fertilizer consumption level of food increased after the food crisis, but remains unstable and unsustainable. The same study shows that the use of fertilizers in the different crop group rate varies. In 2010, the use of fertilizer reached $187 \mathrm{~kg} / \mathrm{ha}$ for cotton and $19 \mathrm{~kg} / \mathrm{ha}$ for food crops (maize and rice) as it was observed [18]. In total, $19 \%$ of cultivation areas used fertilizers in Togo [43], 25\% according to CAGIA [CAGIA: Central Supply and Agricultural Inputs Management of Togo]. These results show that many agricultural area remains to be fertilized if we wants to achieve the objectives of agricultural growth and reach zero hanger in Togo.

Table 1 presents the situation of fertilizer consumption by crop category. 
Table 1 : Import and consumption of fertilizers in Togo in the last decade

\begin{tabular}{|c|c|c|c|c|c|c|c|c|c|}
\hline \multirow{3}{*}{ Total } & \multirow{3}{*}{ Use of Inputs } & \multicolumn{8}{|c|}{ Import and consumption of fertilizers in food crops and for cotton in Togo } \\
\hline & & 2000 & 2005 & 2006 & 2007 & 2008 & 2009 & 2010 & 2011 \\
\hline & & \multicolumn{8}{|c|}{ Import } \\
\hline & Tons & 40700 & 32300 & 31200 & 20900 & 23200 & 32400 & 37300 & 54500 \\
\hline Cotton production & $\%$ & 86 & 86 & 79 & 64 & 60 & 23 & 20 & 36 \\
\hline Food Crops production & $\%$ & 14 & 14 & 21 & 36 & 40 & 77 & 80 & 54 \\
\hline \multirow[t]{2}{*}{ Elements of fertilizers } & & 19600 & 15800 & 15000 & 10000 & 11100 & 14900 & 17100 & 25400 \\
\hline & & \multicolumn{8}{|c|}{ Consumption } \\
\hline Total & Tons & 31500 & 36200 & 21900 & 19400 & 12400 & 34300 & 36600 & 25600 \\
\hline Cotton production & $\%$ & 82 & 77 & 53 & 73 & 20 & 27 & 29 & NA \\
\hline Food Crops production & $\%$ & 18 & 23 & 47 & 27 & 80 & 73 & 71 & 25600 \\
\hline Elements of fertilizers & Tons & 15200 & 17400 & 10300 & 9200 & 5600 & 15900 & 16900 & 11600 \\
\hline
\end{tabular}

Source: B. Balique, 2012.

The amount of subsidies given by the State annually, are not reach many farmers in rural areas. The majority of this budget is immobilized in residual stocks for working capital. Since 2008, the subsidy has reached averaged 2.8 billion Currency of the Africa Financial Community Francs (FCFA) and reached 5.2 billion before falling to 600 million FCFA in 2010 [3]. Unfortunately, the mechanism grant does not encourage all farmers. Only the farmers near roads and those who are in contact with the extension service and whose have financial capacity is high benefit from this grant. Only $10 \%$ of farmers have contact with them, this number is very low compare to $54 \%$ (agriculture population in Togo) small farmers whose livelihoods are marginalized in this grant mechanism [3].

The national cereal balance has been positive due to the support fertilizer policy. In fact, following our investigation on agricultural productivity in Togo, this increase may be due to the increase of cultivation areas but not of increase of yield per hectare. Although there was a slight increase in yield at the corn $(6 \%)$ with an oscillating around 1.2 tons / ha and $20 \%$ increase of cultivation areas [22].

Togolese soils are largely deficient in NPK: 15-15-15 [14]. Despite that Togo has a phosphate deposit in Hahotoè, one of the most abundant on the continent estimated at about 2 billion tons and containing 35\% P2O5 reserve are not known by Togolese farmers because of the absence of a straightforward policy of promoting the use of the local mineral resource. The results of some search carryout showed that this NPK: $15-15-15$ has economically profitable effect in partially acidulated form or direct application in areas where the soil $\mathrm{pH}$ is adequate [14].

\subsubsection{Capital and credit markets}

Credit markets and capital in rural areas of Togo like of developing countries are recognized to be imperfect in the sense that the interest rate paid by poor people is much higher than the market rate and often they simply afford (e.g. micro-credit/FUCEC in Togo). The reasons for this are the presence of risk and asymmetric information in agriculture. Togo no longer has a national system of credit after the liquidation of the National Fund Credit of Agriculture (CNCA) since 1988. Many Banks in Togo refused to finance food crops farmers in agricultural sector because of the risks associated with climatic hazards. But, the cotton farmers do not face the same difficulties [2]. Because cotton farmerse benefits from the system of financing established by the NSCT (New Cotton Company of Togo) to allow its farmers to use new agricultural technologies implemented. The problem of financing the agricultural sector is barrier the adoption of new technologies and the improvement of agricultural productivity. The Togo can also draw on success experiences of other countries in Asia and neighboring countries that succeed to finance their farmers.

Due to the risk of non-repayment, financial institutions prefer to lend to workers and particularly for land owners as they use their property as collateral for loans. Many farmers in Togo are landless, so they cannot have access to credit, owning machine and or accessing fertilizers for agricultural production. They have access to cheaper credit from some OGNs and associations to acquire capital goods for agricultural production. But, this financial market still very narrow for them and many could not access to credit due to the difficulties faces in the repayment. For many moneylender, the rate of repayment remain very higher $(2 \%$ to $100 \%$ ) and for some microcredit financial service provider rate of repayment is more than $2 \%$ /month during the production season [3].

It is clear that unlike the imperfections in the labor market imperfections on the credit markets and capital have an adverse effect on the efficiency of small farms at a given level of labor. They ensure that the opportunity cost of investing in capital is higher for small homeowners and landowners. For this reason, it is expected that there is a substitution of labor to capital in large farms.

\subsubsection{Theory of sharecropping}

Sharecropping is very common phenomenon in rural areas of Togo. While the majority of owners of small farms cultivate themselves their property, landowners of lager"s agricultural areas put their land under contract. There are two types of 


\section{International Journal of Science and Research (IJSR) \\ ISSN (Online): 2319-7064}

Index Copernicus Value (2013): 6.14 | Impact Factor (2014): 5.611

contracts that are common in Togo: the tenancy for a fixed rent and sharecropping. Lease is to allow a farmer to cultivate the land for his own benefit in exchange for a fixed rent he pays to the owner. Sharecropping, meanwhile, is to share the production with the owner in proportions of land.

\section{Methodology}

\subsection{Study Area}

The study was carried out in State of Togo Which has the land's size of 21,925 square meter $(56,785 \mathrm{~km} 2)$ and the population of 7,12 million [43] with an average population density of 253 people per square mile $(83 \mathrm{hbt} / \mathrm{km} 2$-DESA, 1997) and $110.8 \mathrm{hbt} / \mathrm{km} 2$ in 2010 , [7] and $113.160 \mathrm{hbt} / \mathrm{km} 2$ [43], with annual growth rate of 2.08 per cent.

The climate is generally tropical with average temperatures ranging from $23{ }^{\circ} \mathrm{C}\left(73^{\circ} \mathrm{F}\right)$ on the coast to about $30{ }^{\circ} \mathrm{C}(86$ ${ }^{\circ} \mathrm{F}$ ) in the northernmost regions, with a dry climate of a tropical savanna. To the south there are two seasons of rain (the first between April and July and the second between September and November), even though the average rainfall is not very high.

\subsection{Data Resource}

The data of this study were culled from Ministry of Agriculture of Togo (MAEP-Togo), ICAT [ICAT: Technical Support and Advising Institute of Togo] and field survey. The study was conducted five (5) geopolitical regions namely from southern to northen as follow: Maritime, Plateaux, Centrale, Kara and Savane. A total of 408 smallholder farming households were randomly targeted for this survey where a representative sample was drawn from each region from in 2015 base on the proportionate to size procedure.

\subsection{Data Analysis and Model Specification}

The study used descriptive analyses such as table, graphs, means and standard deviation to describe distribution of farmers ,households according to farm characteristics and productivity. The relationship between agricultural production and production factors is analyzed using OLS and Cobb-Douglas model. It's hypothesized that increasing the productivity of these factors in rural areas, will contribute to improve agricultural productivity through farmeres ability to increase their skill and knowledge on how to use production inputs and specially the new technology in agriculture.

\subsection{Empirical model and Model Specification}

The study use Cobb-Douglas Production function, which takes into account a number of $\mathrm{n}$ inputs (production factors) and has variable production elasticity, can be expressed as follow:

$$
Y=f(L, L a, K, \text { Fert }, S d)
$$

Where $\mathrm{L}$ is land; $\mathrm{La}$ is Labor; $\mathrm{K}$ is capital; Fert is Fertilizer, $\mathrm{Sd}$ is Seed.
A generalization of the Cobb-Douglas production function that has variables production elasticity and may be specified as follows:

$$
\log Y=\beta_{0}+\sum_{i}^{n} \beta_{i} \log X_{i}+\sum_{l} d l D l+\mu_{i}
$$

Where the dependent variables (quantity of fertilizer use) is $\mathrm{Y}$ and independents variables (household characteristics and others factors) are $\mathrm{Xi}$ affected input use in the production process. The constant $\beta_{0}, \beta_{i}, \mu_{i}$ are the parameters to be estimated. Where;

$\mathbf{Y}=$ is Quantity of input use $(\mathrm{kg})$

$\boldsymbol{\beta}_{i}=$ measures elasticity,

$\mathbf{X i}=$ Farm size, farming experience, household size, duration of education, access to market and belonging to farm group.

$\boldsymbol{\mu}_{i}=$ Term of error

$\boldsymbol{\beta}_{0}=$ indicates the interaction effects between the continuous variables $i$ and $j(i, j=1,2, \ldots, n)$,

$\mathbf{d l}=$ is a measure of the effect of the difference between regions or measures the deviation of the mean effect of dummy variable

Dl $=$ Regional dummy

Table 2: Description of variables [The dependent and explanatory variables used here are: Land, labor, machinery, education level of the household head, crop yield, fertilizers, pesticides, soil quality, and climate condition. Besides these, the other explanatory variables refer to dummy gender of the household head, dummy indicating]

\begin{tabular}{|c|c|c|}
\hline Descriptions & Measurement & Expectation sign \\
\hline Age & Number of year & $+/-$ \\
\hline Gender & $\begin{array}{c}\text { Male=1 } \\
\text { Female=0 }\end{array}$ & $+/-$ \\
\hline Head of household & & $+/-$ \\
\hline Head education Level & Duration & $+/-$ \\
\hline Household size & & $+/-$ \\
\hline Farm size & Hectare & $+/-$ \\
\hline $\begin{array}{c}\text { Distance to the nearest } \\
\text { market of input/sell }\end{array}$ & $\mathrm{Km}$ & $+/-$ \\
\hline
\end{tabular}

Table 3: Descriptive variables

\begin{tabular}{|c|c|c|c|c|}
\hline Variable & Mean & Std. Dev. & Min & Max \\
\hline Age & 42.375 & 12.004 & 21 & 76 \\
\hline Marital Status & 2.04902 & 0.325 & 2 & 5 \\
\hline Primary School & 0.2867647 & 0.453 & 0 & 1 \\
\hline Middle School & 0.296568 & 0.457 & 0 & 1 \\
\hline High School & 0.058823 & 0.235 & 0 & 1 \\
\hline Household Size & 7.110294 & 3.647 & 1 & 24 \\
\hline Farming Experiences & 5.514706 & 6.617 & 0 & 40 \\
\hline Farm Size & 2.068297 & 4.276 & 0.24 & 42.5 \\
\hline Extension Contact & 2.073529 & 4.421 & 0 & 48 \\
\hline $\begin{array}{c}\text { Maize Seed } \\
\text { Cos(FCFA) }\end{array}$ & 40764.12 & 87844 & 0 & 660000 \\
\hline Fertilizer Cost & 27500 & 12313 & 0 & 33000 \\
\hline Total Cost & 68264.12 & 9118 & 0 & 693000 \\
\hline Total Production/year & 2555.82 & 5606 & 50 & 49500 \\
\hline
\end{tabular}

\section{Results and Discussion}

\subsection{Characteristics of household farmer producing maize}




\section{International Journal of Science and Research (IJSR) \\ ISSN (Online): 2319-7064 \\ Index Copernicus Value (2013): 6.14 | Impact Factor (2014): 5.611}

The age, gender and education level of a farmer are important factor used to determine household capabilities in production and the influence on farming experience and ownership of production factor such as land, adoption of agricultural new technology.

\subsubsection{Household age and gender}

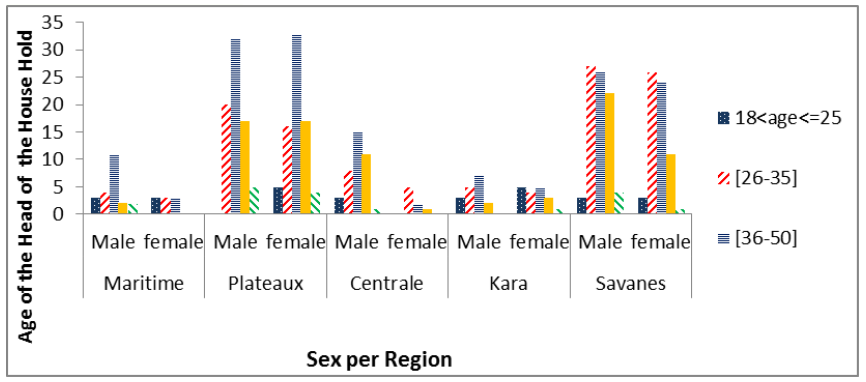

Figure 1: Age per gender

Result in Figure 1 shows the age and gender of the household for every region. It can be observed that a total of 408 respondents ${ }^{\text {ee }}$ responded whereby $57 \%$ of the respondents are male and $42 \%$ are female. Also, $36 \%$ of most of households farmers living in Plateaux rural areas, this finding is similar to the one found during the national survey in 2013 [20]. This region contributes a lot on food production in Togo. Most of the household head are male; this means that most of the decision is taken by them in production crop system.

The same Figure 1, shows that the age of the majority of farmers lies between 35 and 50 year old represented by $45 \%$. With low number (almost quarter $(27 \%)$ ) of the farmer's age between 18 and 35 years, this is the group of youth which has energy and expected to boost production.

\subsubsection{Farmer's Education Level}

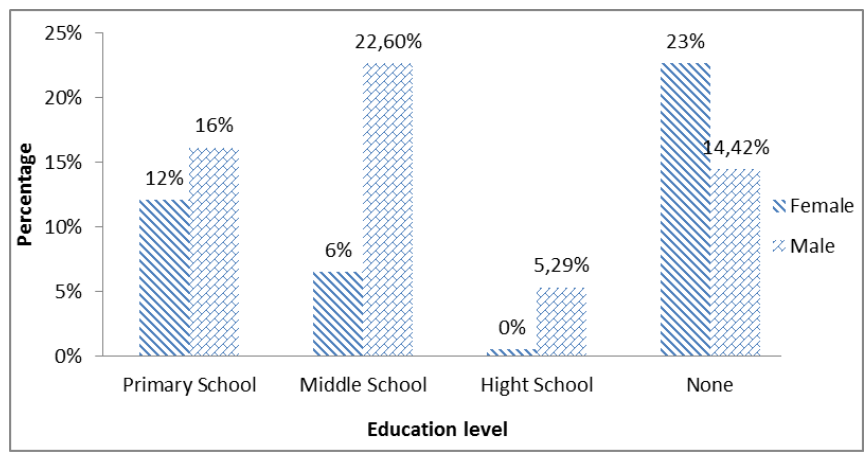

Figure 2: Education level of the households

Result in Figure 2 represents respondents ${ }^{\text {ee }}$ responses on education level of households.

In order to see capabilities and knowledge of the household to adopt agricultural new technology, education is used to measure the effect. The Figure 2 shows that $28 \%$ of household have primary school level, 28,6\% have middle school level and only $6 \%$ have high school level, while minimum of $0.25 \%$ have university and adult education. It was surprising to see that more than one third of the population $(37 \%)$ has never been to school. This shows that there is so much population with very low level education or no education. This indicated that agriculture has never attracted educated people which are reported by many African countries. This result can explain why farmers have not been able to adapt agricultural new technology like machines, fertilizers and new variety seed to improve their agricultural productivity. Even for those who are using they don't know proper application of fertilizer application and many of them don't know how to do good agricultural practice in their farm [13].

\subsubsection{Household cultivation areas and Land Ownership}

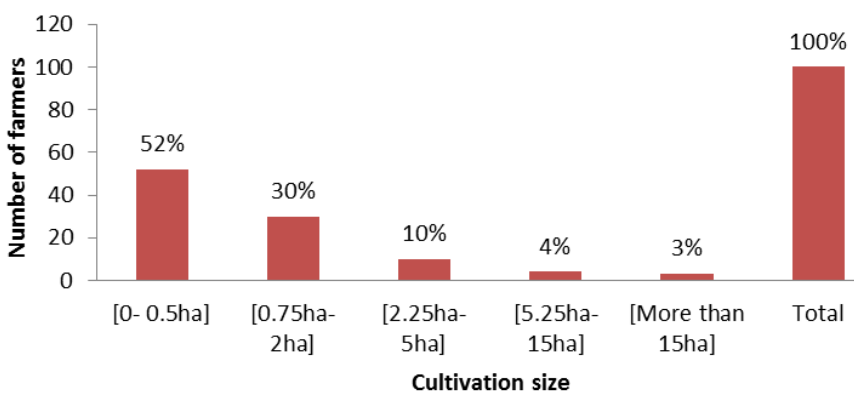

Figure 3: Cultivation areas

The result in Figure 3 shows that the farmers own the areas size from $0-0.5$ hectares are small scale farmers and middle scale farmers owning the land between $0.75-2$ hectares.

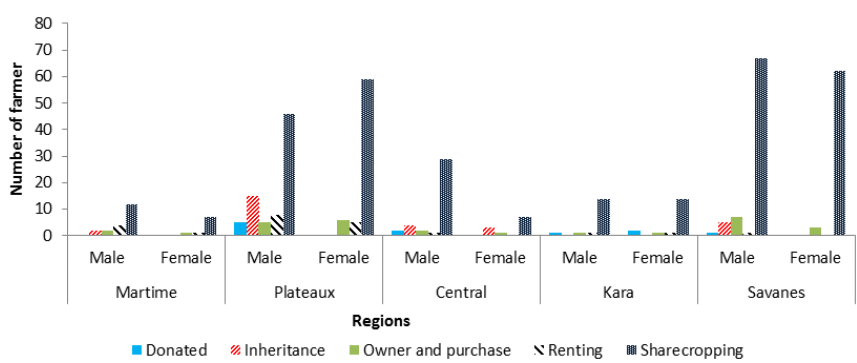

Figure 4: Land Ownership

Regarding access to land, the majority of farmers are likely to share their production with the land owner who gave them land for cropping. Figure 4 shows that sharecropping system is held by $76 \%$, followed by inheritance $9 \%$, land owner with land $7 \%$ and renting land were only $5 \%$. This situation shows difficulty that farmer has in obtaining bank loans or micro finance to buy the necessary inputs. It is therefore, necessary to revisit the land reform to empower farmers and easy access to bank credit.

\subsubsection{Use of fertilizers}

Results of the fertilizers, seeds improvement, machinery used and other problems link to erosion, credit and livestock alimentation in the study areas are in the following part of this paper. 


\section{International Journal of Science and Research (IJSR) \\ ISSN (Online): 2319-7064}

Index Copernicus Value (2013): 6.14 | Impact Factor (2014): 5.611

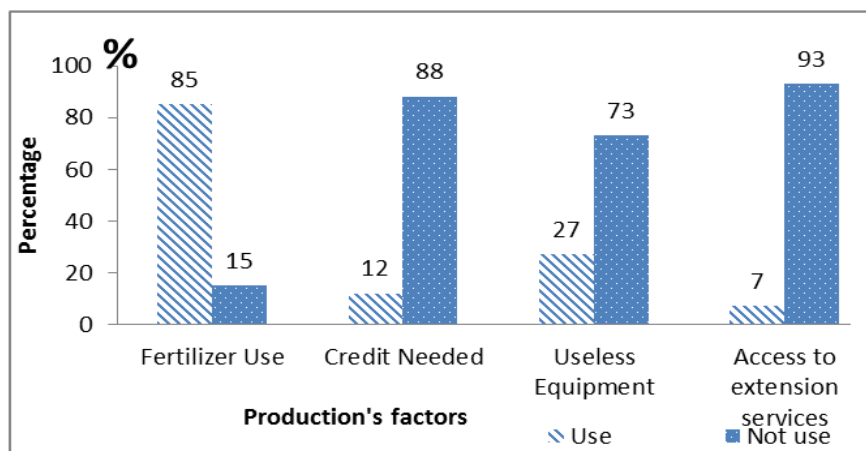

Figure 5: Production"s factors

Figure 5 shows that many farmer do not have access to extension services. Only $7 \%$ of the farmers have access to extension and $27 \%$ of farmers have adequate facilities for their agricultural activities. Almost $88 \%$ of farmers need credit for agriculture production, which paralyzes the financing of activities related to the production, material goods, and even for commercial. However, yields remain low, following the misapplication of these inputs. Not all farmers are able to adopt technology due to the small number of extension workers they have, and the fact that it comprises many measures that require a high level of knowledge from farmers [9].

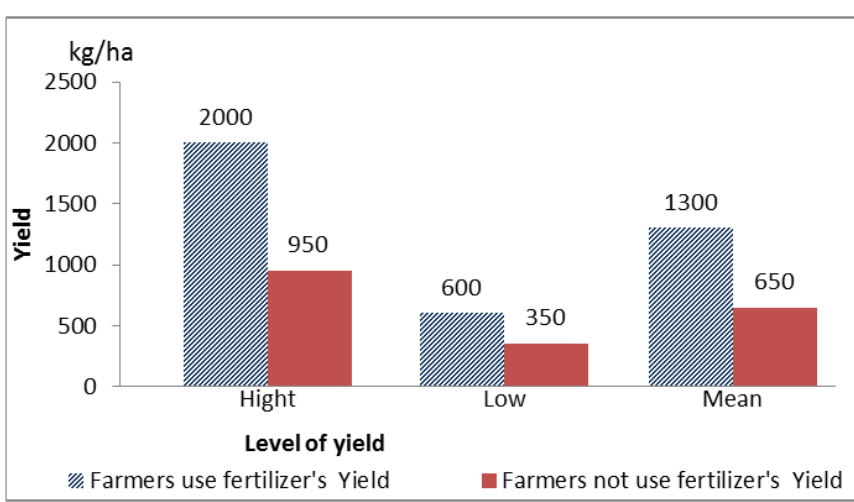

Figure 6: Households ${ }^{\text {ee }}$ Yield based on fertilizer use or not

Figure 6 shows that among those who use fertilizers, there are farmers who manage to get good performance to $2000 \mathrm{~kg} / \mathrm{ha}$. But, farmers who get poor performance (e.g. $600 \mathrm{~kg} / \mathrm{ha}$ ) are certainly those who improperly apply fertilizers or are victims of climatic hazard.

Beside those who use agricultural inputs, the study found that there are farmers who don't use agricultural inputs. The yield is still very low among these farmers. It is therefore, advises that farmers"e awareness for application of improved seeds and use of agricultural inputs is necessary. The tools used by most of the farmers are traditional local hand tools.

\subsection{Reasons for low adoption in new agricultural technology by farmers}

Table 4: Result from Cobb-Douglas Model to determinants of factors affected input use in maize production

\begin{tabular}{|c|c|c|c|c|c|c|}
\hline \multirow{4}{*}{ Independent variable } & \multicolumn{6}{|c|}{ Dependents Variables } \\
\hline & \multicolumn{2}{|c|}{ NPK:15-15-15 } & \multicolumn{2}{|c|}{ Seed } & \multicolumn{2}{|c|}{ Urea } \\
\hline & $\begin{array}{l}\text { For All } \\
\text { Farmers }\end{array}$ & $\begin{array}{c}\text { For farmers with farm } \\
\text { size less than } 1.5 \text { ha }\end{array}$ & For All Farmers & $\begin{array}{c}\text { For farmers with } \\
\text { farm size less } \\
\text { than } 1.5 \mathrm{ha}\end{array}$ & $\begin{array}{l}\text { For All } \\
\text { Farmers }\end{array}$ & $\begin{array}{c}\text { For farmers } \\
\text { with farm size } \\
\text { less than } 1.5 \text { ha }\end{array}$ \\
\hline & \multicolumn{6}{|c|}{ Coefficients } \\
\hline Farm size & $0.1796^{* * *}$ & $1.2986 * * *$ & $0.1771 * * *$ & $1.2277 * * *$ & $0.1798 * * *$ & $1.271 * * *$ \\
\hline Farming experience years & 0.0056 & -0.0061 & 0.00658 & -0.0021 & 0.0053 & -0.005 \\
\hline Age & & & -0.0018 & $0.00169^{*}$ & -0.00178 & 0.0004 \\
\hline Head of household & $0.4891 * * *$ & $0.0870 * * *$ & $0.4628 * * *$ & $0.0635 *$ & $0.4668 * * *$ & $.05637^{*}$ \\
\hline Duration of education & -0.0049 & 0.0014 & -0.0084 & -0.00221 & -0.0032 & $0.0045^{*}$ \\
\hline Household size & $-0.02146^{* * *}$ & 0.0005 & $-0.023 * * *$ & -0.00475 & $-0.0199 * * *$ & 0.0009 \\
\hline Belonging to farm group & $0.22682 * * *$ & -0.0003 & $.2197 * * *$ & 0.01182 & $0.2162 * * *$ & -0.00858 \\
\hline Access to market & 0.004 & $0.0062 * * *$ & 0.0028 & $0.0061 * * *$ & 0.00237 & $0.00428 * *$ \\
\hline Maritime & 0.1238 & -0.0155 & 0.13243 & 0.03465 & 0.105829 & -0.01776 \\
\hline Plateaux & $-0.6276^{* * *}$ & $-0.0976^{*}$ & $-0.599 * * *$ & -0.0714 & $-0.6143 * * *$ & $-0.1018 *$ \\
\hline Centrale & 0.0521 & -0.0551 & 0.0752 & -0.0226 & 0.0562 & -0.056 \\
\hline Savanah & $-0.4449 * * *$ & -0.0147 & $-0.414 * * *$ & 0.0029 & $-0.4147 * * *$ & 0.01146 \\
\hline cons & $4.9145 * * *$ & $3.9938 * * *$ & $3.398943 * * *$ & $2.4096^{* * *}$ & $4.2635^{* * *}$ & $3.2756 * * *$ \\
\hline Number of observation & 384 & 287 & 386 & 289 & 386 & 289 \\
\hline $\mathrm{F}(11,275)$ & 67.48 & 227.79 & 61.25 & 174.07 & 60.82 & 203.08 \\
\hline Prob > F & 0 & 0 & 0 & 0 & 0 & 0 \\
\hline R-squared & 0.7606 & 0.8765 & 0.7669 & 0.8619 & 0.7624 & 0.8808 \\
\hline Root MSE & 0.54696 & 0.20688 & 0.52826 & 0.21051 & 0.53966 & 0.19746 \\
\hline
\end{tabular}

Note: *** Significant at $\mathrm{P}<0.01$; **Significant at $\mathrm{P}<0.05$; * Significant at $\mathrm{P}<0.10$;

\section{At all farmers level}

Table 4 from Cobb-Douglas regression shows that for the use of NPK: 15-15-15, Seed and Urea the coefficients of farm

\section{Volume 5 Issue 1 January 2016}




\section{International Journal of Science and Research (IJSR) \\ ISSN (Online): 2319-7064}

Index Copernicus Value (2013): 6.14 | Impact Factor (2014): 5.611

size, head of household and farm cooperative membership have positive sign and statistical significant at $\mathrm{p}<0.01$ level of probability. This implies that increase in farm size, gender of the head of household and farm cooperative membership have positive influence on the input use by $17 \%, 48 \%$ and $22 \%$ for NPK: $15-15-15 ; 17 \%, 46 \%$ and $21 \%$ for Seed and $17 \%, 47 \% 22 \%$ for Urea. And in addition learning from neighbors "experience is important determinants of adoption [12]. The head household's gender affects positively the choice of fertilizer use. The household size has negative sign and statistically significant at $\mathrm{p}<0.01$ level of probability. This means that the number of person living in the household influence the choice of using fertilizer or not.

The results for regional dummy variable show that the NPK: 15-15-15, seed and Urea use"s coefficient are negative and statistically significant at $\mathrm{p}<0.01$ level of probability. This implies that in Plateaux and Savanah regions farmers are not using fertilizer in good way, which affected their output negatively. This finding imply that, a unit increase of NPK: $15-15-15$, Seed and Urea use, decrease the production by $63 \%$ and $41 \%$ for NPK: $15-15-15,59 \%$ and $41 \%$ for Seed and $61 \%$ and $41 \%$ for Urea respectively for Plateaux and Savanah ${ }^{\text {ee }}$ regions. The law of minimum is required to allow crop growing. Balanced nutrition is needed to obtain maximum yield and avoid shortages of nutrients.

The evidence from the analysis using adjusted R-square revealed that the eight independent variables contributed up to $76 \% ; 77 \%$ and $76 \%$ percent of the systematic variation in the agricultural fertilizers and seeds use in agricultural production respectively for NPK:15-15-15, Seed and Urea.

\section{Conclusion and Recommendations}

This study focused on the factors affecting inputs application in rural areas in Togo. The econometric evidence obtained from the study showed that the overall contribution of the eight independent variables (farm size, farming experience years, age, head of household, duration of education, household size, belonging to farm cooperative, and access to market) on the input use of major agricultural commodities (e.g. maize) were very significant in the model specified.

It was also observed that Access to market was significant for small farmers. This implies that, the less the distance between the inputs market and farmers, the more the use is.

In the study of [9], he explains that small land size of the household, ineffective infrastructure facilities and limited capacity of extension workers are main drivers that led to low agricultural technology use

There is no doubt that agriculture would be one of the key routes to Togo "s development in the future if the government and private sectors give more attention on it. Agricultural development will provide opportunity to majority and boost the export of agricultural produce as a result will increase economy of individual and the nation at large.

Therefore, to ensure increase in agricultural input use, the country should adequate supply and distribution inputs evenly and timely in every cropping season, as well as ensuring availability of credits to rural farmers.

\section{Future Scope}

This study recommends future research to focus on how to allowed farmer access to training and better understanding of how to use fertilizers. This could be done with more implication of extensiones agent. Attract the attention of policy makers on the strategy to liberalize the inputs market by encouraging the private sector implication.

\section{References}

[1] Andzio-bika, H. L. W., \& Wei, L. (2005). Agricultural productivity growth and technology progress in developing country agriculture: case study in China. Journal of Zhejiang University SCIENCE, 6(Suppl. I), 172-176. doi:10.1631/jzus.2005.AS0172

[2] Anyanwu SO. (2013). Determinants of aggregate agricultural productivity among high external input technology farms in a harsh macroeconomic environment of IMO State, Nigeria. African Journal of Food, Agriculture Nutrition and Development, Volume 13 No 5. PP:8238-8248

[3] Benjamin Balique, (2012). Master memory on "Une Politique d"Etat en faveur du Développement du Marche des Engrais au Togo". Ministry of Agriculture and husbandry and Fishery of Togo

[4] Boserup, E. (1965). The Conditions of Agricultural Growth, Aldine, Chicago.

[5] Desai, B. M., and John W. Mellor, (1993). International Food Policy Research Institute. Institutional finance for agricultural development: an analytical survey of critical issues.

[6] Egli, D.B. (2008). Comparison of corn Soybean yields in the USA-Historical trends and future Prospects. Agronomy Journal 100, S78-79.

[7] FAO. (2013). Food and Agriculture Organization of the United Nations. 2012. The state of food insecurity in the world 2012: Economic growth is necessary but not sufficient to accelerate reduction of hunger and malnutrition. Rome: FAO.

[8] FAO/ MAEP. (2013). Volume_I_Overview General Agriculture Togolese RNA2012 15Juillet201 3.

[9] Farah Adila Abdullah and Bahaman Abu Samah, 2013. Factors Impinging Farmers ${ }^{\text {ee }}$ Use of Agriculture Technology. Asian Social Science; Vol. 9, No. 3; 2013. ISSN 1911-2017 E-ISSN 1911-2025. Published by Canadian Center of Science and Education.

[10] Feder G. and Umali D.L. (1993). The adoption of agricltural innovations: A review. Technol Forecast Soc 43: 215-219.

[11] Feder G., Just R.E. and Zilberman D. (1985). Adoption of Agricultural Innovation in Developing Countries: A survey. Econ Dev Cult Change 33: 255-295.

[12] Hailu B. A. (2008). Literature review: Agricultural Technology Adoption. Adoption of improved tef and wheat Production technologies in crops-livestock mixed Systems in northern and wheat Shewa zones of Ethiopia. 


\section{International Journal of Science and Research (IJSR) \\ ISSN (Online): 2319-7064}

Index Copernicus Value (2013): 6.14 | Impact Factor (2014): 5.611

http://www.fao.org/publications/sofi/en/

[13]ITRA. (2014). Etude de référence, deévaluation et d'analyse des méthodes de diffusion des technologies et d'identification des besoins de services et deinnovation des exploitations agricoles familiales. Identification d'options politiques et stratégiques pour une meilleure adoption des résultats de la recherche par les exploitations agricoles familiales en Afrique de $1^{\text {e'Ouest. }}$ Projet AGRIFAM-CORAF/WECARD.

[14]ITRA/IFDC-Afrique, (1998). Etude de faisabilité de l'utilisation du phosphate naturel dans les zones de cafécacaco et coton de la Région des Plateaux au Togo. ITRA/IFDC. Lomé,Togo-460 • February 2007

[15] Keijiro Otsuka, (2000). Role of agricultural research in poverty reduction: Lessons from the Asia experience. Food Policy 25: 447-462.

[16] Leathers and Smale, (1991). Maize Technology in Malawi: A Green Revolution in the Making? CIMMYT Research Report. No 4

[17] MAEP (2013). Final evaluation of the 2012_2013 crop production. Ministry of Agriculture of Togo.

[18] MAEP/B.BALIQUE, (2012). Une Politique deEtat en Faveur du Développement du Marche des Engrais au Togo. Rapport Définitif.

[19] MAEP/DSID. (1997). National Survey of Agriculture Sector in 1996: Togo Agriculture Characteristics Structure. Final Report.

[20]MAEP/FAO,(2013). Volume_I_Overview General_Agriculture_Togolese_RNA2012_15Juillet201 3. National survey of agriculture sector.

[21] MAEP/PASA.(2013). Rapport final de l'Etudes du Marche de l'Engrais au Togo.

[22] MAEP/PNDA. (2012). National Agriculture Policy Togo (2012).

[23] Mariapia Mendola, (2006). Agricultural technology adoption and poverty reduction: A propensity-score matching analysis for rural Bangladesh. University of Milano-Bicocca and Centro Studi L. deAgliano, Milano, Italy. Journal of Food Policy. Food Policy 32 (2007) 372-393.

[24] Maryjane, U., \& Celestine, U. (2013). Analysis of Micro Credit as a Veritable Tool for Poverty Reduction among Rural Farmers in Anambra State, Nigeria. Discourse Journal of Agriculture and Food Sciences, 1(October), 152-159. Paradigm and Policy, pp 63-71

[25] Mundlak, Y. (2007). "Agricultural Productivity" and Economic Policies: concepts and Measurements" OECD working paper. No. 75 OECD Development centre.

[26] Ofuoku,A.U. \& Agbamu, J.U. (2012). Influence of Farmerse Group Cohesion on Adoption of Climate Change Adaptation Strategies in Delta State, Nigeria. Global Journal of Science Frontier Research Agriculture and Veterinary Sciences Volume 12 Issue 6 Version 1.0 April 2012 Type : Double Blind Peer Reviewed International Research Journal .Publisher: Global Journals Inc. (USA) Online ISSN: 2249 -4626 \& Print ISSN:0975-5896.

[27] Perz, S. G. (2003). Social Determinants and Land Use Correlates of Agricultural Technology Adoption in a Forest Frontier: A Case Study in the Brazilian Amazon, 31(1).
[28]Pichón, Francisco \& Bilsborrow, Richard E. (1999). "Land-use systems, deforestation, and demographic factors in the humid tropics: Farm-level evidence from Ecuador." In Richard Bilsborrow and D. Hogan (Eds.), Population and deforestation in the humid tropics (pages 175-207). Liege, Belgium: International Union for the Scientific Study of Population

[29]Pichón, Francisco. (1997). "Colonist land allocation decisions, land use and deforestation in the Ecuadorian Amazon frontier." Economic Development and Cultural Change 45(4),707-744.

[30] Place, Frank Otsuka, Keijiro, (2000). Population pressure, land tenure, and tree resource Management in Uganda. Land Economics 76(2): 233-251. http://orcid.org/0000-0002-1216-8308 Place, Frank; IFPRI-3 ISI IFPRI Division FCND. http://ebrary.ifpri.org/cdm/singleitem/collection/p15738c oll5/id/2017/rec/14

[31] PNUD. (2012). Rapport final de "access to transformation et conservation of smallholders farmers in Togo"

[32] Rauniyar G \& Goode F. (1992). Technology adoption on small farms. World Development 20: 275-282.

[33] Rauniyar, G. P. and F. M. Goode (1996). "Managing Green Revolution Technology: An Analysis of a Differential Practice Combination in Swaziland." Economic Development and Cultural Change 44(2): 413-437

[34] Richard E. Bilsborrow, (2002). MIGRATION, POPULATION CHANGE, AND THE RURAL ENVIRONMENT. ECSP REPORT• ISSUE 8. (SUMMER 2002): 69-94. University of Michigan Population-Environment Fellows Programes Population, Environmental Change, and Security Working Paper Series. Copies are available on-line at http://www.sph.umich.edu/pfps/bilsborrow.pdf

[35] Rosegrant, M. R., Hazell, and P.B.R., (1999). Transforming the Rural Asian Economy: The Unfinished Revolution. Oxford University Press, Hong Kong.

[36] Ruttan, Vernon W. (2002). "Productivity Growth in World Agriculture: Sources and Constraints." Journal of Economic Perspectives, 16(4): 161-184. DOI: $10.1257 / 089533002320951028$

[37] Sibusiso Moyo, George W. Norton, Jeffrey Alwang, Ingrid Rhinehart, and C. Michael Deom, (2007). Peanut Research and Poverty Reduction: Impacts of Variety Improvement to Control Peanut Viruses in Uganda. American Journal of Agricultural Economics 89(2):448I

[38] Sidi S., Moussa S., Aliou D. Marie-Noelle Ndjiondjop, Dogbe S. Y., M. M. Coulibaly, P. Y. Adegbola, (2012). An Institutional Innovation for Agricultural Technology Adaptation and Adoption: Rice in West and Central Africa. CORAF/WECARD, SENEGAL. Sociology Study ISSN: 5159-5526 Nov. Vol.2 Num. 16: 848-867.

[39] Smeeding, Timothy M. and Daniel H. Weinberg. (2001). "Toward a Uniform Definition of Household Income." Review of Income and Wealth series 47 no. 1 (March), pp. 1-24.

[40] Thirtle, C, Lin, L, \& Piesse, J. (2003). The Impact of Research-Led Agricultural Productivity Growth on Poverty Reduction in Africa, Asia and Latin America. 
World Development, 31(12), 1959-1975. doi: 10.1016/j.worlddev.2003.07.001.

[41]Ugbajah,M. O. and Chidebelu, S.A.N.D.(2012). Comparative Analysis of Access to Financial Services by Rural Farmers in Anambra State, Nigeria. International Journal of Applied Research and Technology.1(8): 18-23

[42] Usman Haruna, Mohammed Bashir Umar, (2011). Agricultural Development for Food Security and Sustainability in Nigeria. Global Food Security: Rethinking Agricultural and Rural Development

[43] World Bank,2015: Country data based updated in 2015. http://data.worldbank.org/country/togo

[44] World Conference of Environmental Economics, (1998). Some Determinants to Agricultural Productivity-an application to the Kenya highlands.

[45]Zeller M., et al. (1997). Rural finance for food security for the poor: Implications for research and policy, food policy review;4,p.118

\section{Author Profile}

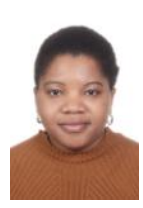

Gbete Wasseh Emefa Germaine received the Diploma of Agro-economist Engineer in 2009 (Major: rural economy) and Master degree in April, 2012 in Economics of Agriculture, Food and the Environment at National Institute Agronomic of Tunisia (INAT). During 2012- 2013, she works as Program Coordinator of Inputs trade and transport at New Cotton Company of Togo (NSCT-Togo). From September 2013, she is doing her research for $\mathrm{PhD}$ degree in International Information Division (IID), Agricultural Information Institute (AII) at Chinese Academy of Agricultural Sciences (CAAS), 12 Zhongguancun South Street, Haidian, 100081 Beijing, China.

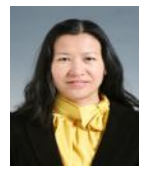

Prof. Nie Fengying is Deputy Director of International Information Division (IID) at Agricultural Information Institute (AII), in Chinese Academy of Agricultural Sciences (CAAS), 12 Zhongguancun South Street, Haidian, 100081 Beijing, China. She completed her $\mathrm{PhD}$ from CAAS and since then she has been involved with various agriculture related policy studies in China and globally. 